\title{
HIP 装置の新技術紹介一新形急冷方式・ガス回収能力強化について
}

\author{
渡邊 克充* \\ (株)神戸製鋼所＼cjkstart機械事業部門産業機械事業部重機械部技術室， $=$ 676-8670 高砂市荒井町新浜 2 丁目 3-1.
}

\section{New Technology Introduction of the HIP Equipment}

\author{
Katsumi WATANABE* \\ Engineering Section, Heavy Machinery Department, Industrial Machinery Division, Machinery Business, KOBE STEEL, LTD., \\ 2-3-1, Shinhama Arai-cho, Takasago 676-8670, Japan.
}

Received September 17, 2018; Revised November 27, 2018; Accepted November 28, 2018

\begin{abstract}
HIP is a technology to simultaneously apply high pressures and temperatures to processed products by gas. HIP equipment applying HIP technology is used as an indispensable technology for densification of sintered products, removal of pores in casting and diffusion bonding of dissimilar materials.

In this article, we will explain the history of the development of HIP equipment in Japan, then the introduction of new technology of the rapid cooling method and the HIP equipment with enhanced gas recovery capacity, aiming at productivity improvements of the HIP process, both of which were newly developed by our company.
\end{abstract}

\section{KEY WORDS}

HIP, rapid cooling, productivity

\section{1 まえがき}

HIP (Hot Isostatic Pressing：熱間等方圧加圧）は，ガスに より高い圧力と高温を同時に処理物へ加える技術である. HIP 技術を応用した HIP 装置は，焼結体の緻密化，鋳造品の 巣や気孔の除去，金属粉末の高密度焼結や異種材料の拡散接 合などに不可欠な技術として利用されている1).これまで当 社は 350 台以上の HIP 装置の納入実績があり, 現在では国内 シェアトップの高圧 HIP 装置メーカとして, その地位を確立 している.

本稿では，日本における HIP 装置の開発の歴史，克服され てきた課題について紹介するとともに，当社において新しく 開発した, HIP 処理の生産性向上を目的とした，急速冷却方 式とガス回収能力強化 HIP 装置について, 新技術を紹介する.

\section{2 日本における HIP 装置開発の歴史}

日本における HIP 装置の開発は，50 年以上前，1960 年代 に研究用小型高圧ガス装置の開発から始まった。その後, 超 硬合金，高速度鋼，フェライトなど，様々な材料に対応した HIP 装置が開発され，現在では，広く工業用途で使われてい

* Corresponding author, E-mail: watanabe.katsumi@kobelco.com
る2). Table 1 に弊社で開発した主要な HIP 装置を示す。

HIP 装置の開発において, 様々な課題が克服されてきた が, その中で最も大きな課題の一つが, 処理雲囲気の多様化 であった。

HIP 装置では，一般的に，圧媒ガスとしてアルゴンガスを 使用する。これは, 高温高圧雲囲気下での圧媒ガスと非処理 品の反応を防ぐためであるが, 強力な還元䨌囲気となるた め, 酸化物や窒化物の処理には不向きであった. 日本では, HIP 技術の窒化物セラミックスなどへの適用が広がるととも に，アルゴンガス以外の䨌囲気，例えば，窒化ケイ素セラ ミックスの為の窒素䨌囲気や, 酸化物セラミックスの為の酸 素混合アルゴン䨌囲気を扱うことができる HIP 装置が求め られてきた。当社では, 窒素 HIP 装置, 酸素 HIP 装置や隔壁 HIP 装置などを開発し, これらの要求に応えてきた.

生産性の向上も, 大きな課題の一つであった. HIP 装置は, 高圧ガスを扱うために, 肉厚の圧力容器が必要であり, 一般 的な熱処理装置と比較して装置コストが大きくなる。また, 大型装置では, 昇温・昇圧, 冷却やガス回収工程に非常に長 い時間を要し，1バッチに丸一日以上を要する場合があり， 処理コストを押し上げる要因となっていた，当社では，1970 年代に処理品搬送を格段に効率化するボトムローディングシ 
Table 1 Typical development of HIP equipment accomplished by KOBELCO.

\begin{tabular}{ll}
\hline Developed technology & Year \\
\hline Small R\&D high pressure gas equipment & 1964 \\
Production HIP for cemented carbide parts & 1971 \\
Production HIP for high speed tool steel billets & 1977 \\
Production HIP with bottom loading system & 1977 \\
Production HIP for soft ferrite & 1978 \\
Nitrogen HIP unit & 1981 \\
Modular HIP system for soft ferrite production & 1982 \\
Oxygen HIP unit for R\&D of ceramics & 1986 \\
Oxygen HIP unit for commercial production & 2002 \\
Oxygen partial pressure control HIP & 2002 \\
Mechanical properties testing equipment in hydrogen & 2003 \\
New Rapid cooling method & 2015 \\
\hline
\end{tabular}

ステムを開発, 1980 年代には圧力容器外で余熱・冷却を可能 とするモジュラーHIP システムを開発するなど，初期から生 産性向上に取り組んでおり，近年の装置大型化に伴い，冷却 やガス回収工程などプロセス時間の短縮にも取り組んできた。

\section{3 急速冷却方式}

Fig. 1 に大型装置における HIP プロセスの例を示す。眓か らわかるように, HIP プロセスにおける冷却とガス回収時間 の割合は非常に大きく，これらの工程を短縮することで，大 幅な生産性向上を図ることができる，特に冷却工程は全体に 占める割合が大きいため, 急速冷却方式の開発は, 当社にお いても長年の課題であった.

HIP 装置では，発熱体が配置されている処理空間と圧力容 器の間には，処理空間の高温から熱を遮断するための断熱 層が配置されている，HIP装置内の高圧・高温ガスは，例え ば, $100 \mathrm{MPa}, 1000^{\circ} \mathrm{C}$ といった圧力・温度の場合, 密度が水 の $30 \%$ 程度と非常に大きく，一方で粘性は水の $10 \%$ 程度と 小さく，かつ，熱膨張係数が大きいので，激しい対流を生じ やすく，ガスの流動による熱伝達が非常に大きい。このため, 断熱層は，ガスの対流を生じないような構造をとり，ガスの 流動による熱移動を遮断することで, 圧力容器内面の温度が

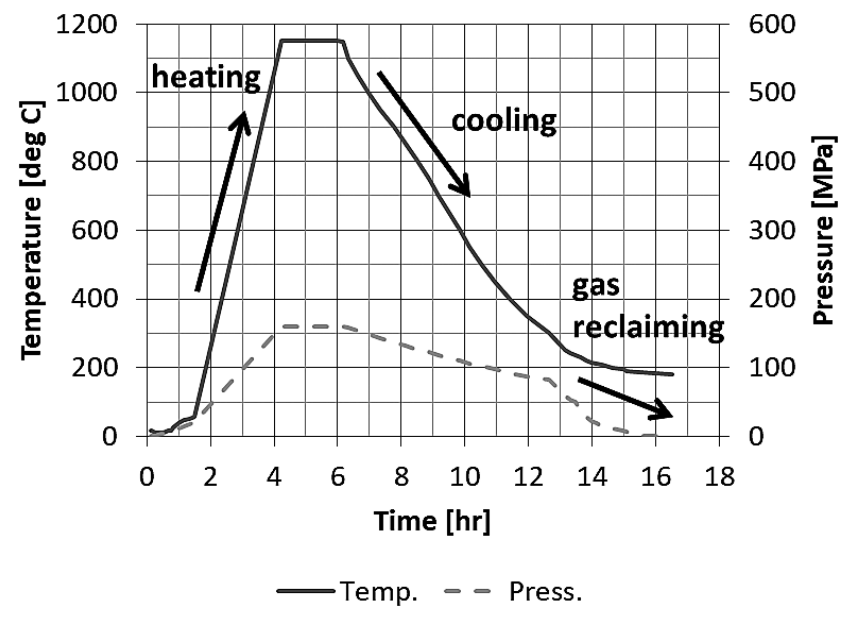

Fig. 1 Example of HIP processing.
一定以下に保たれるように設計されている．冷却の工程を短 縮するためには，断熱層によって制限されているガスの流動 を冷却過程のみ促進し，処理空間から断熱層の外側への熱移 動が多くなるようにすればよい。すなわち，処理空間内の高 温ガスを断熱層の外側へ導き，高温ガスと圧力容器の間の熱 交換によって, 処理空間内の熱を直接的に圧力容器外へ排出 すればよい。このとき，断熱層の外側へ導かれた高温ガスに よって圧力容器の内面温度が上昇する。圧力容器は高強度合 金鋼で製作されるが，高強度合金鋼は温度の上昇に伴い強度 低下するため, 圧力容器の内面温度は, 設計温度以下に保つ 必要がある。このため, 処理空間から断熱層の外側への熱移 動は, 圧力容器の内面温度を設計温度以下に保つ程度に制限 する必要があり, 当社で採用していた単肉容器では, 十分な 熱移動量が得られず，冷却工程の短縮は限定的であった。

\section{4 新しく開発した急速冷却方式}

単肉容器でも十分な熱移動量を確保するため, 当社では, ガスの流れを工夫した新しい急速冷却方式を開発した。（以 降, “新急冷方式”と呼ぶ. )

Fig. 2 に新しく開発した急速冷却方式を採用した加熱装置 の模式図を示す。この加熱装置では，断熱層の外側と内側の それぞれに，圧媒ガスを上方へ導く整流筒が配置されてい る. 冷却ファンからの循環流がこの整流筒によって断熱層の 外側と内側のそれぞれに導かれ，二重の循環流を生成する. 断熱層と外側整流筒の間を通り断熱層上方へ導かれ，外側 整流筒と圧力容器の間を通ってファンに戻る流れを，“第一 循環流”（Fig. 2 の Flow “A”）と呼び，内側整流筒と断熱層 の間を通り処理室上方へ導かれ，処理室を通過した後に第一 環流と合流しファンへ戻る流れを，“第二循環流”（Fig. 2 の Flow “B”) と呼ぶ.

一般的に, ガスと圧力容器内面の熱伝達は, 圧力容器内面 を流れるガスの流速により，流速が大きければ大きいほど熱 伝達率は大きくなる，従来の急速冷却方式では，前述の“第 二循環流”のみで急速冷却を実現しており，圧力容器内面の 熱伝達率は第二環流の流量による。処理空間から出た高温ガ スは圧力容器内面へ直接導かれるため, 圧力容器内面温度が 


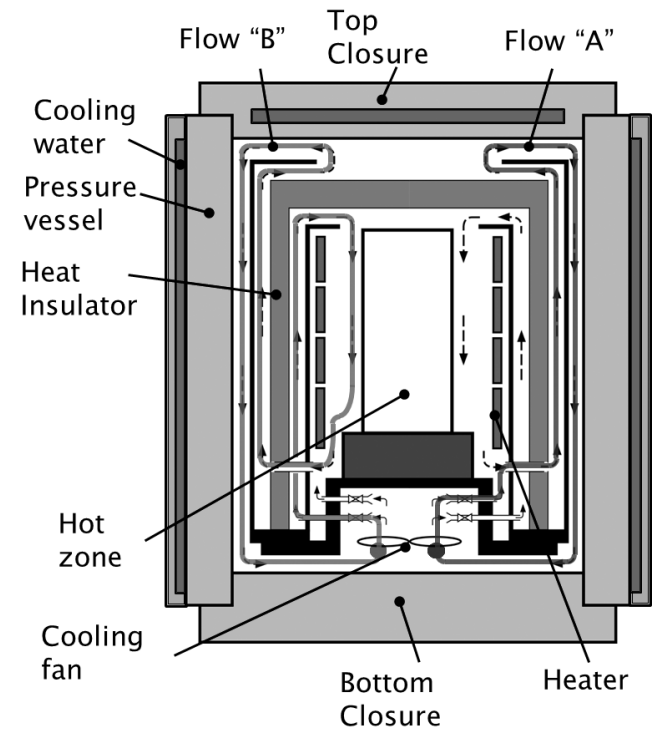

Fig. 2 New rapid cooling furnace.

上がりすぎないように，ガス流量を制限する必要がある。す なわち, 最大ガス流量が制限され，同時に冷却速度も制限さ れる。

一方，新急冷方式では，第一環流は処理空間を通らないた めガス温度が低く、第二環流のような流量の制限を受けな い. このため, 圧力容器内面を流れるガスの流速を大きくす ることができ, 圧力容器内面の熱伝達率を十分大きくするこ とができる，また，第二環流は第一環流によって圧力容器内 面に導かれる前に冷却されるため，第二環流のみの場合と比 較して, 圧力容器内面温度が上がりにくく, 流量を大きく取 ることができる.

このように圧力容器内面温度を低く保ったまま流量を増や

\section{Conventional furnace}

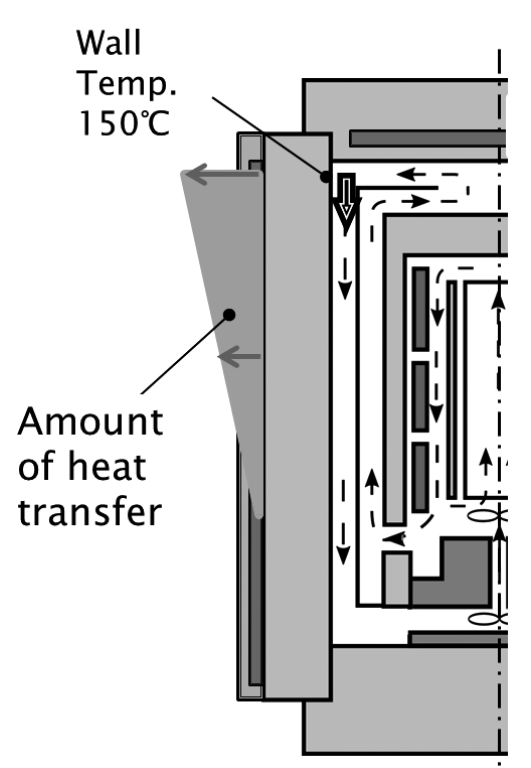

すことができるようになり, Fig. 3 に示すように, 圧力容器 内面から外への熱移動量を大きくすることができ, 単肉容器 でも十分な熱移動量が得られるようになった．圧力容器の設 計を同じとした場合, 新急冷方式では, 従来の急冷方式より も 1.5 倍以上の泠却速度を得ることができる。

\section{5 新急冷方式を採用した商用 1 号機}

2016 年に，新急冷方式を採用した商用 1 号機を製作した。 この装置は，新急冷方式と並行して開発を進めた，ピアノ 線巻内面冷却容器を採用し, 処理室径 $850 \mathrm{~mm}$, 処理室高さ $2500 \mathrm{~mm}$ の大型装置であるが，2 ton の負荷を搭載した状態 で $1400^{\circ} \mathrm{C}$ から $25^{\circ} \mathrm{C} / \mathrm{min}$ で冷却する能力を持つ. Fig. 4 に, $15^{\circ} \mathrm{C} / \mathrm{min}$ で制御しながら冷却した結果を示す．本装置の場 合, 従来の急速冷却方式では, $15^{\circ} \mathrm{C} / \mathrm{min}$ で冷却するために は, 圧力容器内壁温度を $200^{\circ} \mathrm{C}$ 以上とする必要があるが, 新 急冷方式では, 圧力容器内壁温度を $120^{\circ} \mathrm{C}$ 以下として $15^{\circ} \mathrm{C} /$ min の冷却速度を確保できることを確認できた.

Fig. 5 に，急速冷却を使用した場合の HIP プロセスの例を 示す. Fig. 1 に示したHIP プロセスを鎖線で重ねて示してい る. 図からわかるように，急速冷却によって冷却工程が 5.5 時間短縮され，プロセス時間がこの例の場合は 16.5 時間か ら 11 時間となり, 約 1.5 倍の生産性向上を実現することがで きた。

\section{6 ガス回収能力強化 HIP 装置}

冷却能力向上とともに，ガス回収能力向上も, HIP 装置の 生産性向上に大きな効果を得られる。一般的に HIP 装置で は, 高圧ガス系統の各機器が高価であり, ガス回収能力強化 はコストの面で不利であるが， $700^{\circ} \mathrm{C}$ 程度の比較的低い温度 で HIP 処理し，処理後は冷却せずにガス回収を行い $500^{\circ} \mathrm{C}$ 程

Fig. 3 Comparison of two different furnaces. 


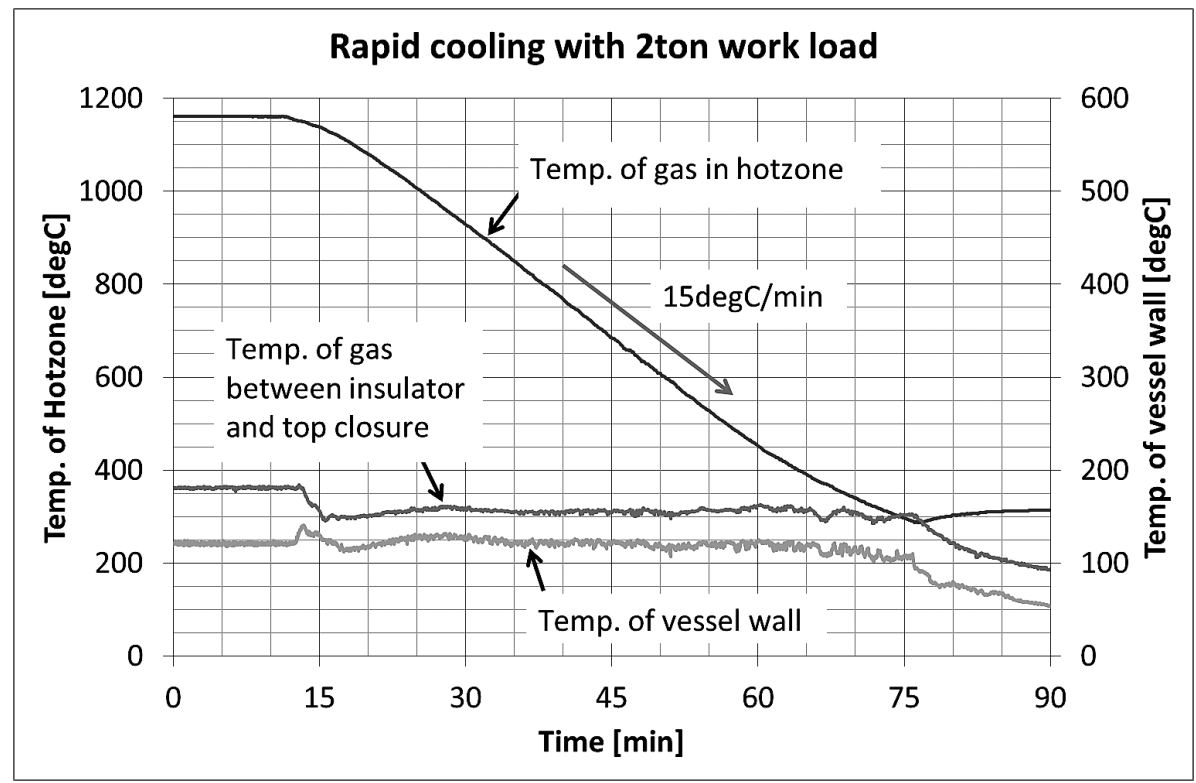

Fig. 4 Results of the rapid cooling controlled in $15^{\circ} \mathrm{C} / \mathrm{min}$.

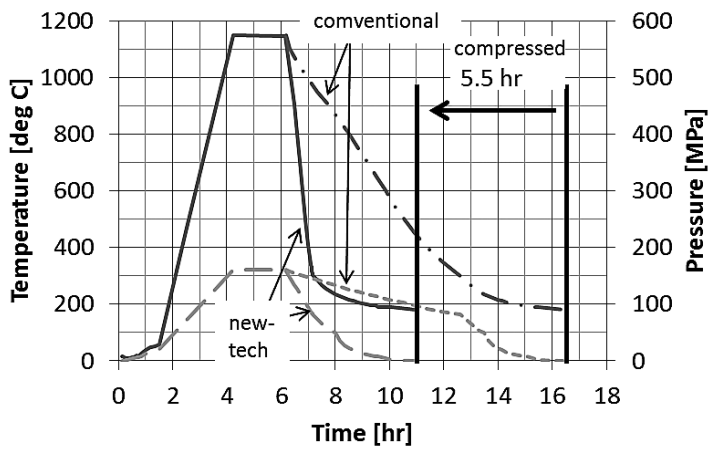

—Temp. (w R.C.) - - Temp. (w/o R.C.)

- -Press. (w R.C.) -----Press. (w/o R.C.)

Fig. 5 Comparison of process time.

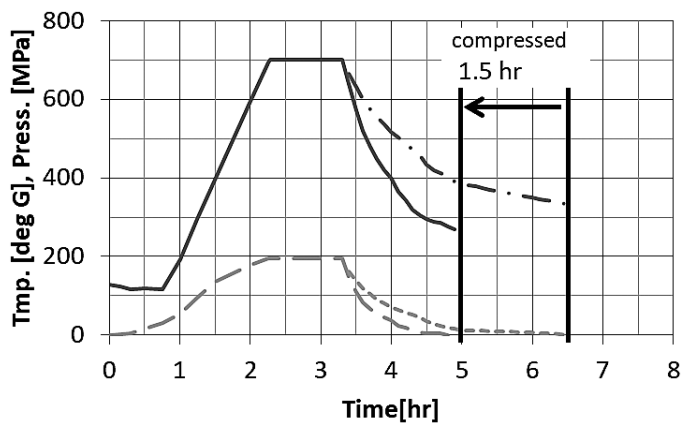

-Temp. (Enhanced) _ - -Press. (Enhanced)

- - Tmep. (Conventional)-----Press. (Conventional)

Fig. 6 Effect of increasing gas reclaiming capacity.

度で処理品を取り出すような高温取出しを採用したプロセス では，ガス回収時間の短縮がプロセス全体に占める割合が大 きく，この方法が生産性向上に大きく寄与する。
Fig. 6 に，ガス回収能力強化 HIP 装置の HIP プロセスの例 を示す． $700^{\circ} \mathrm{C}, 200 \mathrm{MPa}$ で 1 時間保持し，冷却せずにガス 回収し, 大気開放後 $500^{\circ} \mathrm{C}$ 程度で処理品を取り出すプロセス である．この装置では，ガス回収能力を強化するために，ガ ス系統と圧縮機を 2 系統設け，能力を 2 倍とした。これに伴 い，昇圧能力も2 倍となるが，本プロセスは昇温と昇圧を同 時に行う同時昇温昇圧プロセスであり，昇温時間の方が昇圧 時間よりも長いため，昇圧時間の短縮は，プロセス時間短縮 には寄与していない。一方，ガス回収は，系統を 2 倍とした ために時間が半分となった。これから，プロセス時間は， 6.5 時間から 5 時間へ 1.5 時間短縮され，この例では約 1.3 倍の 生産性向上を達成した。

\section{7 まと め}

HIP 装置において，当社では，多様なガス雲囲気に対応す る窒素 HIP 装置，酸素 HIP 装置などを開発するとともに，ボ トムローディングシステム，モジュラーHIPや急速冷却方式 など，生産性向上に関する開発にも取り組んできた。 とくに 急速冷却方式は長年の課題であったが，従来よりも高効率の 急速冷却方式の開発に成功した.この新急冷方式を採用した 商用 1 号機を製作，試運転において，生産性の大幅な向上に 寄与することを確認した。また，ガス回収能力強化 HIP 装置 を開発し，さらなるプロセス時間短縮の可能性を示した.

これからも HIP 装置技術の向上に尽力する所存である.

\section{文献}

1) M. Koizumi, M. Nishihara: Touhou Kaatsu Gijyutsu, Nikkan Kogyo (1988).

2) T. Ishii, T. Fujikawa, Y. Inoue, T. Kanda: KOBE STEEL ENGINEERIG REPORTS 50 (2000) 104-108. 